\title{
Generating revenue by raising tobacco taxes in Latin America and the Caribbean
}

\author{
Mark Goodchild, ${ }^{1}$ Rosa Carolina Sandoval, ${ }^{2}$ and Itziar Belausteguigoitia ${ }^{2}$
}

Suggested citation Goodchild M, Sandoval RC, Belausteguigoitia I. Generating revenue by raising tobacco taxes in Latin America and the Caribbean. Rev Panam Salud Publica. 2017;41:e151. doi: 10.26633/RPSP.2017.151

ABSTRACT Objective. The objective of this study was to determine if raising tobacco taxes in the Latin America and Caribbean (LAC) region will generate extra tax revenue, even at outer edges of the sensitivity analysis, with relatively high price elasticities of demand for cigarettes.

Methods. A model of the cigarette market in 31 LAC countries was developed using cigarette tax, price, and retail sales data for 2014. It was then assumed that all countries increased the excise tax by $50 \%$ per pack. The model incorporated 12 studies from the LAC region that estimate the price elasticity of demand for cigarettes to quantify the expected impact of this tax increase on sales and tax revenues.

Results. The tax increase would raise cigarette prices by an average of $28 \%$ across the region. The volume of cigarette sales would decrease by $7 \%$ (confidence interval (CI): 3-11). Cigarette tax revenue would increase by $32 \%$ (CI: 27-37), representing an extra US\$ 7050 million (CI: 5 984-8 086) in revenue. Almost all countries showed increases in tax revenue, even at outer edges of the sensitivity analysis.

Conclusions. These findings confirm that the expected benefits of raising tobacco taxes are robust across the LAC region. Countries in the region should have confidence that raising tobacco tax rates will generate extra tax revenues.

Keywords Economics; taxes; public health; Latin America; Caribbean region.

Tobacco taxation is one of the core demand-reduction strategies outlined in the World Health Organization (WHO) Framework Convention on Tobacco Control (FCTC) $(1,2)$ and is widely recognized as the single most potent and cost-effective strategy for curbing the demand for tobacco (3-5). Tobacco taxation has been described as a win-win policy

\footnotetext{
World Health Organization, Geneva, Switzerland. Send correspondence to: Mark Goodchild, goodchildm@who.int

2 Pan American Health Organization, Washington, D.C., United States.
}

because raising tax rates on tobacco can generate extra revenue for governments while also reducing tobacco consumption and the associated costs of illness. These twin benefits have been highlighted in various forums, including the Third International Conference on Financing for Development (FfD) held in Addis Ababa, Ethiopia, in July 2015, which produced the Addis Ababa Action Agenda ("Addis Agenda"). The Addis Agenda recognizes that "price and tax measures on tobacco can be an effective and important means to reduce tobacco consumption and health care costs, and represent a revenue stream for financing development in many countries" (6).

Despite taxation being considered one of the most cost-effective interventions to reduce tobacco use, it remains largely under-utilized in the Americas (7). This is largely due to tobacco industry tactics to block, delay, and weaken tobacco control policies. In the case of fiscal policies, governments often refrain from taking action because of claims propagated by the industry that higher taxes will harm economies and decrease tax revenues (5). 
These claims often center on the threat of increased illicit trade, the so-called Laffer effect (i.e., decreased tax revenue), or similar arguments that aim to weaken governments' confidence in the expected relationship between price, demand, and tax revenue.

The strength of tobacco taxation as a means of controlling tobacco use and generating tax revenue hinges most critically on the price elasticity of demand. In empirical studies throughout the world, the price elasticity of demand for cigarettes is consistently found to be relatively inelastic - meaning that the percentage change in demand is less than the percentage change in price $(3,8)$. The inelasticity of demand provides the economic foundation upon which an increase in tobacco tax will decrease consumption yet increase overall tax revenue. To estimate the magnitude of these Effect Sizes (ES) more accurately, models used to forecast the impact of higher tobacco taxes often employ sensitivity analyses using a range of price elasticity estimates.

This study aimed to determine if raising tobacco taxes in Latin America and Caribbean (LAC) countries will generate extra tax revenue, even at the outer edges of the sensitivity analysis, with relatively high price elasticities of demand for cigarettes.

\section{MATERIALS AND METHODS}

The data and methodology for the analysis were primarily derived from a study published in the WHO Bulletin in 2016 by Goodchild et al. (9). Data on taxes and prices for a 20-cigarette pack of the most popular brand in each country for 2014 were sourced from the 2015 WHO report on the global tobacco epidemic (4). In this dataset, the amount of excise and other taxes on cigarettes was calculated in U.S. dollars (US\$) based on each country's tax system. The quantity of licit (i.e., tax-paid) cigarette retail sales in each country was calculated using data from two market survey companiesGlobalData and Euromonitor International $(10,11)$. The dataset included 31 countries from the LAC region.

The retail price that consumers pay for cigarettes can be broken down into tax plus the industry price net of taxes (i.e., costs and profit margins). The tax component will, in turn, depend on the kinds of taxes that each country levies on cigarettes, though most countries apply excise and value-added taxes (VATs). A few countries, such as Belize, and Antigua and Barbuda, levy import or special duties rather than excise taxes. This study took the amount of excise tax (or duty) paid per 20-cigarette pack in 2014 and increased it by $50 \%$ in order to demonstrate the potential impact of a tax increase.

The robust-but not sharp-50\% increase in the excise tax was chosen based on cigarette taxes and prices for the region, although many countries have been raising taxes on tobacco in much larger increments. For example, in May 2016, Peru increased its cigarette excise tax by more than $150 \%$ (from 1.4 to 3.6 soles / pack), and in December 2016, Colombia raised its excise tax on cigarettes by about $100 \%$ (from 701 to 1400 pesos / pack). Another reason for choosing the $50 \%$ increase scenario was that it was expected to increase the retail price of cigarettes overall (region-wide) by an average of about $30 \%$, a level of increase comparable with "real world" experiences. For example, WHO data show that the retail price of cigarettes increased by at least $20 \%$ in one-half of the countries that raised cigarette taxes between 2012 and 2014 and by more than $40 \%$ in one-quarter of them (4).

The model assumed in each country that 1) the industry price (i.e., costs and profit margins) was constant in real terms and 2) the tax increase was fully reflected in the new retail price (i.e., the post-tax increase retail price). While cigarette manufacturers in any country may choose to absorb, or over-shift, some or all of a tax increase, depending on various factors outlined below, the ex ante assumption of full tax pass-through reflects a "middle-ground" approach (i.e., no absorption or over-shift), which is consistent with the regional perspective (9). It also allowed the analysis to focus on the critical relationship between price and consumption: the price elasticity of demand.

The extent to which higher cigarette taxes and prices affect sales volumes is fundamentally determined by the price elasticity of demand. For example, a price elasticity of -0.3 means that a $10 \%$ increase in the retail price of cigarettes will reduce cigarette consumption by $3 \%$. Studies in high-income countries have found elasticities that range from -0.25 to -0.5 , while studies in other countries have found elasticities ranging from -0.2 to -0.8 (8). Guindon et al. (2015) completed a systematic review of price elasticity studies in Latin America and found they are likely to be below -0.5 , with pooled estimates providing an elasticity of -0.31 (CI: -0.24 to -0.39 ) (12).

Table 1 includes data from 1) nine studies selected for this research (12-20) based on their use of time series data to measure consumption and 2) three additional studies (with data for Colombia, El Salvador, and Peru) that have been published since the systematic review (2123). About half of the 12 studies used retail sales data; the other studies created composites of consumption based on official trade and production statistics. The time series studies were selected because they are more likely to reflect the impact of higher prices on the licit market-and hence tax revenues. In other words, studies that use cross-sectional data from household or individual surveys tend to generate lower estimates of the price elasticity of demand in part because they can measure both licit and illicit consumption and therefore might overstate the potential increase in tax revenues (3).

The model incorporated the price elasticities for the 12 countries listed in Table 1 to calculate the impact of a $50 \%$ increase in the excise tax on cigarette retail sales volumes in all 31 countries included in the model. The 12 core countries shown in Table 1 accounted for close to $90 \%$ of cigarette retail sales in the region $(10,11)$. The pooled elasticity estimates (CI: -0.24 to -0.39$)$ from Guindon et al. (2015) (12) were applied to other highand upper-middle-income countries in the region that do not have studies of their own. However, it seems likely that smokers in lower-middle-income countries may exhibit greater price sensitivity. For example, the studies from Bolivia, El Salvador, and Guatemala showed relatively high elasticities $(-0.85,-0.93$, and -0.74 respectively). Therefore, for other lower-middle-income countries without studies, the model used a simple average of the elasticities in those three countries (-0.84; CI: -0.46 to -1.22$)$.

\section{RESULTS}

In 2014, smokers across the LAC region purchased 10.6 billion packs (or 212 billion cigarettes) from the licit retail market. The vast majority were purchased in South America, reflecting the 
TABLE 1. Research on price elasticity of demand for cigarettes, including study method, type of data, country, country income group, and price elasticity with confidence intervals (Cls), Latin America and the Caribbean, 2014

\begin{tabular}{|c|c|c|c|c|c|c|}
\hline$\overline{\text { Author (year; reference no.) }}$ & Method & Data & Country & Income group & Price elasticity & $\mathrm{Cls}$ \\
\hline Martinez et al. (2015) (13) & VECM $^{a}$ & Sales & Argentina & $U_{M M I C^{b}}$ & -0.15 & -0.11 to -0.19 \\
\hline Alcaraz (2006) (14) & $2 S L S^{c}$ & Sales & Bolivia & $\mathrm{LMIC}^{\mathrm{d}}$ & -0.85 & -0.04 to -1.66 \\
\hline Iglesias et al. (2007) (15) & OLS & P\&T & Brazil & UMIC & -0.27 & -0.10 to -0.40 \\
\hline Maldonado et al. (2016) (21) & $2 S L S$ & Sales & Colombia & UMIC & -0.79 & -0.09 to -1.48 \\
\hline Ramos-Carbajales et al. (2016) (22) & VECM & Sales & El Salvador & LMIC & -0.93 & -0.74 to -1.12 \\
\hline Olivera-Chávez et al. (2010) (18) & OLS & P\&T & Mexico & UMIC & -0.14 & 0.04 to -0.32 \\
\hline Herrera Ballesteros (2013) (19) & OLS & Imports & Panama & UMIC & -0.63 & 0.02 to -1.28 \\
\hline Gonzalez-Rozada \& Ramos-Carbajales (2016) (23) & OLS & P\&T & Peru & UMIC & -0.69 & -0.06 to -1.32 \\
\hline Ramos \& Curti (2006) (20) & 2SLS & Sales & Uruguay & $\mathrm{HIC}$ & -0.34 & -0.15 to -0.53 \\
\hline
\end{tabular}

Source: Various authors as cited.

a VECM: vector error correction model.

${ }^{\mathrm{b}}$ UMIC: upper-middle-income country.

c 2SLS: two-stage least squares.

${ }^{\mathrm{a}}$ LMIC: lower-middle-income country.

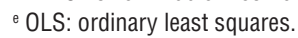

${ }^{\dagger}$ GARCH: generalized autoregressive conditional heteroskedasticity.

${ }^{g} \mathrm{HIC}$ : high-income country.

${ }^{\mathrm{h}}$ Unpublished data cited in (12).

i P\&T: production and trade.

large population of the countries and relatively high rates of adult smoking in that subregion. Total cigarette excise revenue across the LAC region came to US\$ 16.4 billion in 2014. Other taxes, such as VATs, added another US\$ 5.7 billion in tax revenue, resulting in a total tax revenue of US\$22.1 billion.

Table 2 shows the projected impact of raising the excise tax by $50 \%$ per pack in the region. If all LAC countries were to raise excise taxes by $50 \%$ per pack, the weighted average retail price of cigarettes would increase an average of $28 \%$ across the region. Average cigarette retail prices would increase the least in the Caribbean subregion, where baseline prices (net of tax) are relatively high. Smokers would respond to the price increase by purchasing fewer cigarettes, with the overall volume of tax-paid cigarette sales projected to decline by $7 \%$ in 2014 , or a total of 723 million fewer cigarette packs consumed across the region. The quantity of cigarette sales declined by around $7 \%$ across all subregions, but there was a great deal of country variation, with Colombia, El Salvador, Guatemala, and Panama showing decreases in excess of $15 \%$ in this scenario, and many of the Caribbean islands, plus Belize, Mexico, and Paraguay, showing sales decreases of less than $5 \%$.

Under this scenario, total tax revenues from the sale of cigarettes is projected to

TABLE 2. Projected impact of increasing excise tax by $50 \%$ per cigarette pack (change in retail price per pack, sales volume, excise revenue, and total tax revenue): central estimates by subregion/region, Latin America and the Caribbean (LAC), 2014

\begin{tabular}{lcccc}
\hline Variable & The Caribbean & Central America & South America & LAC region \\
\hline Excise tax (US $\$$ pack) & & & & \\
2014 baseline & 1.4 & 1.5 & 1.6 & 1.5 \\
Projection & 2.2 & 2.3 & 2.3 & 2.3 \\
$\%$ change & 50 & 50 & 50 & 50 \\
Retail price (US $\$$ pack) & & & & \\
2014 baseline & 4.4 & 3.1 & 3.1 & 3.1 \\
$\quad$ Projection & 5.3 & 4.0 & 3.9 & 4.0 \\
$\%$ change & 19 & 30 & 27 & 28 \\
Cigarette sales (millions of packs) & & & & \\
2014 baseline & 208 & 2179 & 8219 & 10606 \\
Projection & 196 & 2041 & 7645 & 9882 \\
Change & -12 & -138 & -574 & -723 \\
$\%$ Change & -6 & -6 & -7 & -7 \\
Excise tax revenue (US\$ millions) & & & & \\
2014 baseline & 300 & 3353 & 12752 & 16405 \\
Projection & 423 & 4771 & 17532 & 22726 \\
Change & 122 & 1418 & 4780 & 6321 \\
$\%$ change & 41 & 42 & 37 & 39 \\
Total tax revenue (US\$ millions) & & & & \\
2014 baseline & 428 & 4268 & 17385 & 22092 \\
Projection & 577 & 5890 & 22675 & 29142 \\
Change & 138 & 1622 & 5290 & 7050 \\
$\%$ change & 32 & 38 & 30 & 32 \\
\hline
\end{tabular}

Source: Author estimates.

increase by around 32\%, representing an extra US\$ 7050 million in revenue for governments across the region. Central America had the highest percentage of increase in total cigarette tax revenues (38\%) versus the 2014 baseline. There was a wide spread of revenue growth across countries, with Argentina, the Bahamas, 
and Mexico recording increases of about $40 \%$. However, all 31 countries included in the model showed positive and robust tax revenue growth.

Table 3 shows the range of outcomes for cigarette sales volume and total tax revenue based on the price elasticity CIs described above. For example, a 50\% increase in the cigarette excise tax per pack is projected to decrease overall cigarette sales volume in the LAC region by $-7 \%$ (CI: -3 to -11). The variation in Effect Size (ES) was greatest for the Central America subregion (-6; CI: -1 to -12 ) and lower-middle-income countries (-12; CI: -7 to -17$)$.

Figure 1 shows the range in ES for cigarette sales volume for 1 ) the 12 core countries listed in Table $1 ; 2)$ the three subregions (Caribbean, Central America, and South America); 3) the LAC region overall; and 4) the three country income groups (lower-middle, upper-middle, and high). The effects in Bolivia, Colombia, and Panama exhibited a relatively high degree of variation, with sales decreasing by more than $20 \%$ at the outer edges of the sensitivity analysis. The sensitivity analysis showed that cigarette sales could increase in some countriesJamaica, Mexico, and Panama-even under the tax increase scenario. Cigarette sales volumes were projected to decrease by $-6 \%$ (CI: -2 to -10 ) in upper-middle-income countries and by $-8 \%$ (CI: -7 to -10$)$ in high-income countries.

TABLE 3. Projected impact of increasing excise tax by $50 \%$ per cigarette pack (change in sales volume and tax revenue): range of estimates by subregion/region and country income group (lower-middle, upper-middle, and high), Latin America and the Caribbean (LAC), 2014

\begin{tabular}{|c|c|c|c|c|}
\hline \multirow{2}{*}{$\begin{array}{l}\text { Subregion/region and } \\
\text { income group }\end{array}$} & \multicolumn{2}{|c|}{ Change in sales volume } & \multicolumn{2}{|c|}{ Change in tax revenue } \\
\hline & Millions of packs & $\%$ & US\$ (millions) & $\%$ \\
\hline The Caribbean & -7 to -18 & -3 to -8 & 120 to 156 & 27 to 36 \\
\hline Central America & -24 to -252 & -1 to -12 & 1284 to 1959 & 30 to 46 \\
\hline South America & -271 to -878 & -3 to -11 & 4580 to 5971 & 26 to 34 \\
\hline LAC region & -303 to -1147 & -3 to -11 & 5984 to 8086 & 27 to 37 \\
\hline $\operatorname{LMIC}^{\mathrm{a}}(n=7)$ & -42 to -105 & -7 to -17 & 42 to 91 & 13 to 28 \\
\hline $\mathrm{UMIC}^{\mathrm{b}}(n=17)$ & -204 to -960 & -2 to -10 & 5065 to 7013 & 27 to 37 \\
\hline $\operatorname{HIC}^{c}(n=7)$ & -57 to -83 & -7 to -10 & 878 to 983 & 33 to 37 \\
\hline
\end{tabular}

Source: Author estimates.

a $\mathrm{LMIC}=$ lower-middle-income country.

${ }^{\mathrm{D}} \mathrm{UMIC}=$ upper-middle-income country.

${ }^{\circ} \mathrm{HIC}=$ high-income country.

FIGURE 1. Projected change (\%) in cigarette retail sales volume, by country, subregion/region, and country income group (lower-middle, upper-middle, and high), Latin America and the Caribbean, 2014

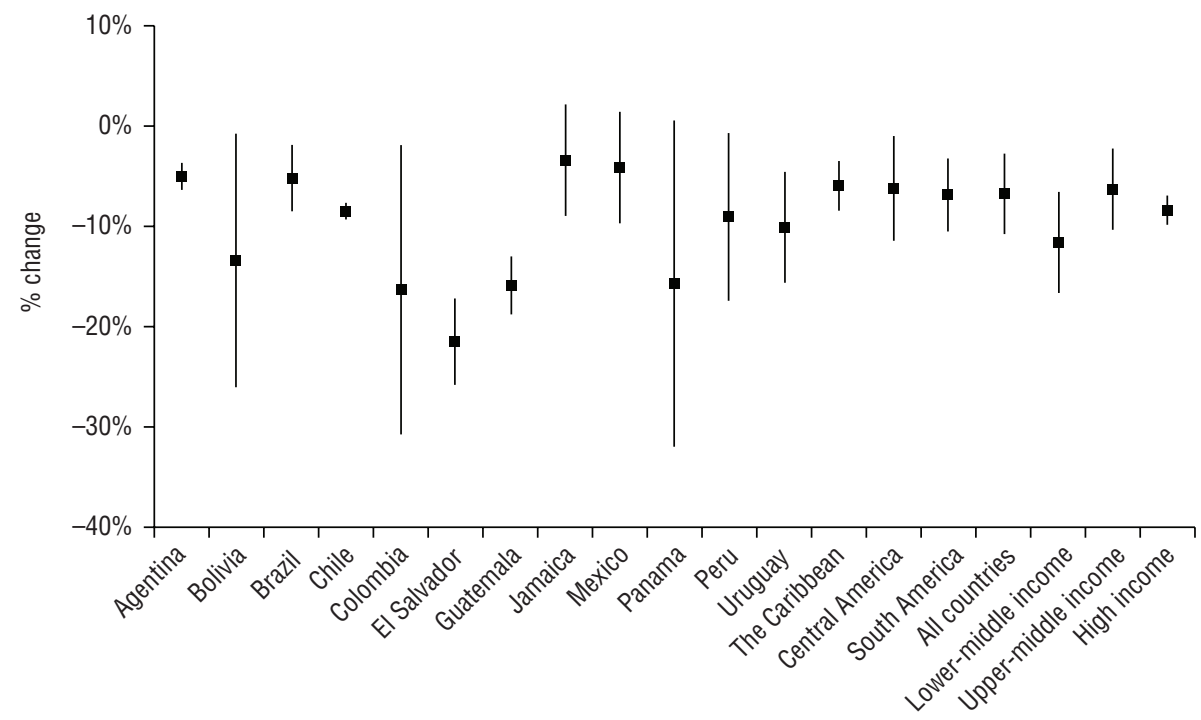

Source: Author estimates.
Figure 2 shows the range in ES for cigarette tax revenue for the same variables (the 12 countries, the three subregions, the LAC region overall, and the three country income groups). Under the tax -increase scenario, all 31 countries included in the model except two (Colombia and Panama) showed increased tax revenue at the outer edges of the sensitivity analysis (i.e., even under the most elastic price scenario). Although the median increase in total tax revenue for Colombia and Panama was around 20\%, both countries had extremely wide CIs, causing the sensitivity analysis to be less definitive in these cases. More than half of the other 29 countries increased their revenue by $20 \%$ or more, even under the relatively high elasticity scenarios.

Raising the excise tax per cigarette pack by $50 \%$ in all of the LAC countries studied would increase overall cigarette tax revenue in the region by $32 \%$ (CI: 27-37), or US\$ 7050 million (CI: 5 984-8 086), which would help create the fiscal space needed by governments to finance their development priorities. If all of the extra revenue from the increased excise tax were allocated to public health budgets, government expenditure on health could increase by $2.5 \%$ region-wide $(24,25)$.

The sensitivity analyses showed that increasing the excise tax per cigarette pack by $50 \%$ would lead tax revenues in the lower-middle-income countries included in the model to increase by $21 \%$ (CI: 13-28). Total cigarette tax revenues in the upper-middle-income countries that were studied would increase by $32 \%$ (CI: 27-37), compared to 35\% (CI: 33-37) in high-income countries. Central America tended to have the strongest performance, showing growth of $38 \%$ (CI: 30-46) in cigarette tax revenues.

\section{DISCUSSION}

This study focused on cigarette retail sales in the licit market in order to assess the impact of higher tobacco taxes on cigarette tax revenues. To assess the impact of higher tobacco taxes on public health outcomes, however, the link between higher prices and the prevalence of smoking must also be considered. Because total cigarette consumption can include the illicit market, the impact of higher prices on smoking prevalence and total consumption could be weaker 
FIGURE 2. Projected change (\%) in total cigarette tax revenue, by country, subregion/ region, and country income group (lower-middle, upper-middle, and high), Latin America and the Caribbean, 2014

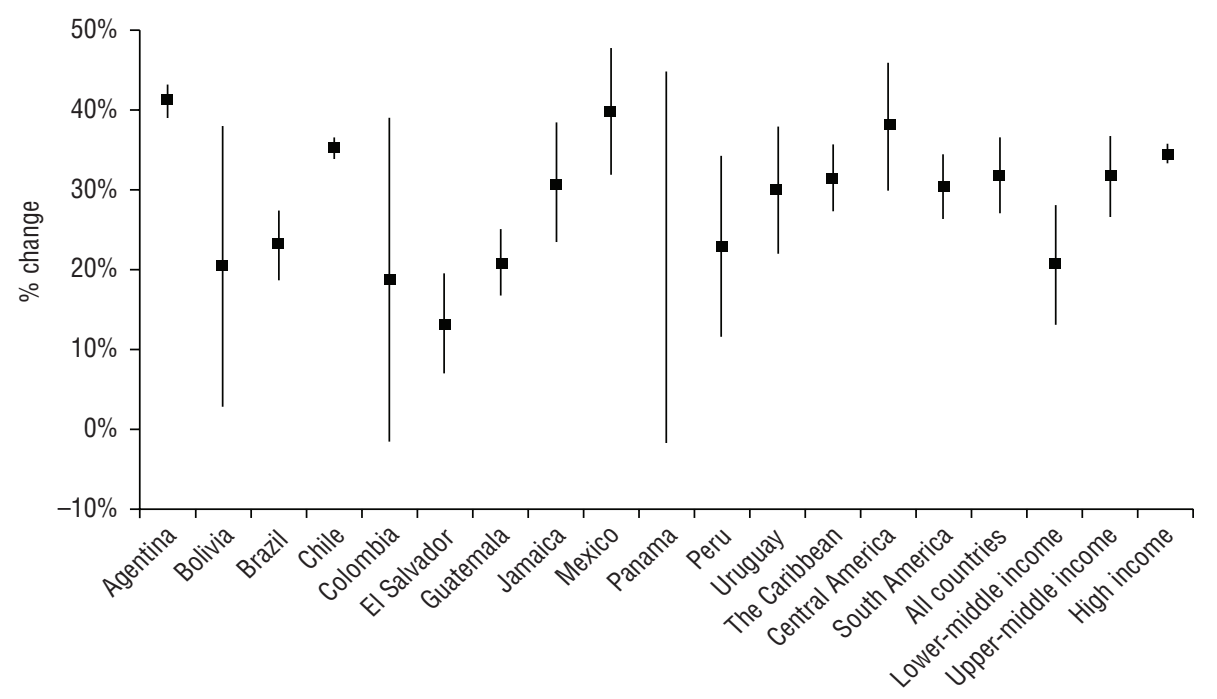

Source: Author estimates.

compared to just the retail market. In other words, researchers might expect the total (i.e., licit and illicit) demand for cigarettes to be relatively more price-inelastic.

Global evidence on the causal relationship between higher cigarette prices and the illicit market is mixed. This is especially the case with "large-scale smuggling" - a form of illicit trade that has the greatest potential to erode the tax base. In this part of the market, other factors, such as ineffective tax and customs administration, and the presence of criminal networks, are important determinants (3). On the regional level, data on the causal relationship between higher cigarette prices and the illicit market are scarce. Nonetheless, the experience in Brazil, where the reform process culminated in a significant increase in taxes on tobacco in 2011, is informative. Studies carried out there show that the reform increased tax revenue, and decreased overall smoking prevalence, despite an increase in the illicit market $(26,27)$ : cigarette excise tax revenues more than doubled between 2006 and 2013, while tobacco use decreased from $34.4 \%$ to $14.7 \%$ of the adult population between 1989 and 2013 (26). Brazil's experience supports the expectation that revenue and health objectives can be achieved even in the presence of smuggling.

Globally, the illicit market is present in low-tax jurisdictions as well as high-tax ones, which suggests it should be treated as a matter of risk management irrespective of the level of price and taxation. On the other hand, Ramos (2009) examined the dynamics of the illicit cigarette market in Argentina, Brazil, Paraguay, and Uruguay, and concluded that price was the main determinant of the illicit market in those countries (28). Nonetheless, experience from across the globe, including in middle-income countries such as Brazil, Kenya, and Turkey, confirms that measures such as tracking and tracing systems, licensing, stronger enforcement, and higher penalties can protect and enhance tax revenue collection (3).

The illicit tobacco trade is a transnational issue that requires greater regional cooperation and coordination, and the global community has a new instrument-the WHO FCTC Protocol to Eliminate Illicit Trade in Tobacco Products ("Illicit Trade Protocol" or ITP)—-to help countries tackle it (29). Once in force, the ITP will require parties to implement a variety of control measures, with emphasis on those that strengthen control over the supply chain and improve cooperation. The ITP provides the blueprint for action against the illicit tobacco trade in the LAC region and worldwide.

\section{Limitations}

There are a number of limitations to this study. First, the analysis did not delve into the exact tax policies needed by each country to raise its excise tax by $50 \%$. Although there are a number of ways countries can achieve this increase, including global best practices outlined in the WHO FCTC Article 6 guidelines, such details are beyond the scope of this study (2). In addition, the analysis assumed there would be a complete pass-through of the tax increase by the tobacco industry in all countries, despite evidence that the extent of the pass-through can depend on a number of factors, such as the cigarette excise structure, the competitive dynamics of the cigarette market, and changes in the wider economic environment $(30,31)$.

For example, evidence from the European Union suggests that specific excise taxes (i.e., those based on quantity) have a greater impact on the retail price of cigarettes than ad valorem excise taxes (i.e., those based on value) (31). A recent study from South Africa found that the extent of under-shifting was significantly reduced by the entry of competitors into the low-price segment of the market (32). Other studies have highlighted the ability of monopolists to cross-subsidize by under-shifting the tax increase on low-price brands while over-shifting the tax increase on premium brands (33). The model's middle-ground assumption of a complete pass-through precluded consideration of the different nuances of each market. However, it also allowed the analysis to focus on the price elasticity of cigarette demand-a determinant for which there is strong country-level evidence from across the LAC region.

\section{Conclusions}

From a broader perspective, the findings of this study confirm that the expected benefits of raising tobacco tax rates are robust across the LAC region. Countries in the region should have confidence that higher tobacco tax rates will generate extra tax revenue and thus help create the fiscal space needed to finance development. The results for almost all of the 31 LAC countries studied showed solid increases in tax revenue from an increase in excise tax on cigarettes, even at the outer edges of the sensitivity analysis, with "high" price elasticities. The study also highlights that risk management measures to control the supply chain and 
improve cooperation among countries at the regional level will help protect and enhance the benefits of higher taxes from both the fiscal and public health perspective.
Conflicts of interest. None.

Disclaimer. Authors hold sole responsibility for the views expressed in the manuscript, which may not

\section{REFERENCES}

1. World Health Organization. WHO Framework Convention on Tobacco Control. Geneva: WHO; 2003. Available from: http://apps.who.int/iris/bitstre am/10665/42811/1/9241591013.pdf

2. World Health Organization. Guidelines for implementation of Article 6 of the WHO FCTC. Geneva: WHO; 2014. Available from: http://www.who.int/fctc/guidelines/adopted/Guidelines_article_6.pdf

3. U.S. National Cancer Institute; World Health Organization. The economics of tobacco and tobacco control. NCI Tobacco Control Monograph 21. Bethesda, MD: U.S. Department of Health and Human Services, National Institutes of Health/NCI; 2016. (NIH publication no. 16-CA-8029A). Available from: https://cancercontrol. cancer.gov/brp/tcrb/monographs/21/ docs/m21_complete.pdf

4. World Health Organization. WHO report on the global tobacco epidemic, 2015: raising taxes on tobacco. Geneva: WHO; 2015. Available from: http://www.who.int/ tobacco/global_report/2015/report/en/

5. Etienne CF. Curbing the tobacco epidemic in the Americas [editorial]. Rev Panam Salud Publica. 2016;40(4):198-9.

6. United Nations. Addis Ababa Action Agenda of the Third International Conference on Financing for Development. New York: UN; 2015. Available from: http://www.un.org/esa/ffd/wp-content/ uploads/2015/08/AAAA_Outcome.pdf

7. Sandoval RC, Belausteguigoitia I, Hennis A. The case of tobacco taxation: where we are and to how accelerate its use for public health. Rev Panam Salud Publica. 2016;40(4):200-1.

8. International Agency for Research on Cancer. IARC handbooks of cancer prevention: tobacco control-volume 14 . Effectiveness of tax and price policies for tobacco control. Lyon: IARC; 2011. Available from: https://www.iarc.fr/en/ publications / pdfs-online/prev/handbook14/handbook14-0.pdf

9. Goodchild M, Perucic AM, Nargis N. Modelling the impact of raising tobacco taxes on public health and finance. Bull World Health Organ. 2016;94(4):250-7. doi: 10.2471/BLT.15.164707.

10. GlobalData Plc. GlobalData [Internet]. London: GD; 2015. Available from: https: / / www.globaldata.com

11. Euromonitor International Ltd. Euromonitor International [Internet]. London: EI; 2015. Available from: http://www.euromonitor.com

12. Guindon GE, Paraje GR, Chaloupka FJ. The impact of prices and taxes on the use of tobacco products in Latin America and the Caribbean. Am J Public Health. 2015;105(3):e9-19. doi: 10.2105/ AJPH.2014.302396.

13. Martinez E, Mejia R, Pérez-Stable EJ. An empirical analysis of cigarette demand in Argentina. Tob Control. 2015;24(1):89-93.

14. Alcaraz VO. Economía del control del tabaco en los países del Mercosur y Estados Asociados: Bolivia. Washington: PAHO; 2006. Available from: http://apps.who. int/iris/handle/10665/173237

15. Iglesias R, Jha P, Pinto M, da Costa e Silva VL, Godinho J. Tobacco control in Brazil. HNP Discussion Paper. Washington: World Bank; 2007. Available from: http://siteresources. worldbank.org/HEALTHNUTRITIONANDPOPULATION/Resources / 2816271095698140167 / BrazilTobaccoControl Final.pdf

16. Debrott Sánchez D. Economía del control del tabaco en los países del Mercosur y Estados Asociados: Chile. Washington: PAHO; 2006. Available from: http://iris. paho.org/xmlui/handle/123456789/2811

17. van Walbeek C, Lewis-Fuller E, Lalta S, Barnett J. The economics of tobacco control in Jamaica: will the pursuit of public health place a fiscal burden on the government? Kingston: Ministry of Health; 2005. Available from: http://www.tobaccoecon. uct.ac.za/sites/default/files/image_tool/ images / 405 / Publications / reports / TheEconomics-of-Tobacco-Control-in-Jamaica.Will-the-Pursuit-of-Public-Health-place-aFiscal-Burden-on-the-Government.pdf

18. Olivera-Chávez RI, Cermeño-Bazán R, de Miera-Juárez BS, Jiménez-Ruiz JA, Reynales-Shigematsu LM. El efecto del precio del tabaco sobre el consumo: un análisis de datos agregados para México. Salud Publica Mex. 2010;52 Suppl 2:S197-205.

19. Herrera Ballesteros VH. Análisis de la demanda de tabaco en Panamá y el control del efecto asequibilidad con medidas fiscales y control del contrabando: implicaciones para política fiscal 2000-2011. Panama City: Instituto Conmemorativo Gorgas de Estudios de la Salud; 2013. Available from: http://hdl.handle.net/10625/51992

20. Ramos A, Curti D. Economía del control del tabaco en los países del Mercosur y Estados Asociados: Uruguay. Washington: PAHO; 2006. Available from: http://iris. paho.org/xmlui/handle/123456789/2812

21. Maldonado N, Llorente B, Deaza J. Impuestos y demanda de cigarillos en Colombia. Rev Panam Salud Publica. 2016;40(4)229-36.

22. Ramos-Carbajales A, González-Rozada M Vallarino H. La demanda de cigarillos y el aumento de impuestos en El Salvador. Rev Panam Salud Publica. 2016;40(4):237-42.

23. Gonzalez-Rozada M, Ramos-Carbajales A. Implications of raising cigarette excise necessarily reflect the opinion or policy of the RPSP/PAJPH, the Pan American Health Organization (PAHO), or the World Health Organization (WHO). taxes in Peru. Rev Panam Salud Publica. 2016;40(4)250-5.

24. International Monetary Fund. World economic outlook: too slow for too long. April 2016. Washington: IMF; 2016. Available from: http:/ /www.imf.org/external/pubs / $\mathrm{ft} / \mathrm{weo} / 2016 / 01 /$

25. World Health Organization. Global health expenditure database. Geneva: WHO; 2015. Available from: http://apps.who. int/nha/database

26. Iglesias RM. Increasing excise taxes in the presence of an Illicit cigarette market: the 2011 Brazil tobacco tax reform. Rev Panam Salud Publica. 2016;40(4).

27. Iglesias RM, Szklo AS, Souza MC, de Almeida LM. Estimating the size of illicit tobacco consumption in Brazil: findings from the global adult tobacco survey. Tob Control. 2017;26:53-9. doi: 10.1136/ tobaccocontrol-2015-052465.

28. Ramos A. Illegal trade in tobacco in Mercosur countries. Montevideo: Centro de Investigación de la epidemia de tabaquismo; 2009. Available from: http://www.fctc.org/ images / stories / INB-3/INB3_report_ illegal_trade_in_MERCOSUR.pdf

29. World Health Organization. Protocol to Eliminate Illicit Trade in Tobacco Products. Geneva: WHO; 2013. Available from: http:/ / apps.who.int/iris/bitstream/10665/80873/ 1/9789241505246_eng.pdf

30. Delipalla S, Keen M. The comparison between ad valorem and specific taxation under imperfect competition. J Public Econ. 1992;49(3):351-67. Available from: https: / / doi.org/10.1016/0047-2727(92)90073-O

31 Delipalla $S$, O'Donnell O. The comparison between ad valorem and specific taxation under imperfect competition: evidence from the European cigarette industry. Canterbury: University of Kent, School of Economics; 1998. Available from: http:/ /EconPapers.repec.org/RePEc:ukc: ukcedp:9802

32. Linegar DJ, van Walbeek C. The effect of excise tax increases on cigarette prices in South Africa. Tob Control. 2017; pii. doi: 10.1136/tobaccocontrol-2016-053340.

33. Marsh L, Cameron C, Quigg R, Hoek J, Doscher C, McGhee R, Sullivan T. The impact of an increase in excise tax on the retail price of tobacco in New Zealand. Tob Control. 2016;25(4):458-63. doi: 10.1136/ tobaccocontrol-2015-052259.

Manuscript submitted 6 March 2017. Revised version accepted for publication on 1 June 2017. 
RESUMEN

\section{Generar ingresos al aumen- tar los impuestos al tabaco en América Latina y el Caribe}

Palabras clave
Objetivo. El objetivo de este estudio fue determinar si aumentar los impuestos al tabaco en América Latina y el Caribe generaría ingresos fiscales adicionales, incluso por fuera del extremo superior del análisis de sensibilidad, con una elasticidad relativamente alta de la demanda de cigarrillos con respecto al precio.

Métodos. Se elaboró un modelo del mercado del cigarrillo en 31 países de América Latina y el Caribe utilizando datos sobre impuestos, precio y ventas minoristas de cigarrillos correspondientes al 2014. Luego se adoptó el supuesto de que todos los países aumentaban el impuesto al consumo de tabaco un $50 \%$ por paquete. El modelo incorporó 12 estudios de América Latina y el Caribe que estimaron la elasticidad de la demanda de cigarrillos con respecto al precio para cuantificar la repercusión prevista de este aumento de impuestos sobre las ventas y los ingresos fiscales.

Resultados. El aumento de los impuestos aumentaría el precio de los cigarrillos un $28 \%$ promedio en toda esta región. El volumen de la venta de cigarrillos disminuiría alrededor de 7\% (intervalo de confianza [IC]: 3-11). Los ingresos derivados del impuesto a los cigarrillos aumentarían en 32\% (IC: 27-37), lo que supondría ingresos adicionales por US\$ 7050 millones (IC: 5 984-8 086). En casi todos los países se observó un aumento de los ingresos fiscales, incluso por fuera del extremo superior del análisis de sensibilidad.

Conclusiones. Estos resultados confirman que los beneficios previstos del aumento de los impuestos al tabaco son sólidos en toda América Latina y el Caribe. Los países de esta región deben confiar en que el aumento de las tasas impositivas al tabaco generará ingresos fiscales adicionales.

Economía; impuestos; salud pública; América Latina; región del Caribe.
RESUMO

Geração de receita com o
aumento dos impostos dos
cigarros na América Latina e
no Caribe

Palavras-chave
Objetivo. Determinar se o aumento dos impostos que incidem sobre os cigarros na Região da América Latina e Caribe (ALC) gera receita tributária adicional, mesmo nas extremidades da análise de sensibilidade, com elasticidade do preço relativamente alta na demanda por cigarros.

Métodos. Um modelo do mercado de cigarros em 31 países da ALC foi desenvolvido com a inclusão de dados sobre imposto, preço e vendas a varejo de cigarros em 2014. Pressupôs-se que todos os países efetuaram um aumento do imposto especial de consumo em 50\% por maço de cigarro. O modelo se baseou em 12 estudos da Região da ALC que estimaram a elasticidade do preço na demanda por cigarros para quantificar o impacto esperado do aumento do imposto na receita tributária e das vendas.

Resultados. O aumento do imposto resultaria em um aumento médio no preço dos cigarros de $28 \%$ em toda a Região. O volume de vendas de cigarros sofreria uma queda de $7 \%$ (intervalo de confiança (IC): 3-11). A receita do imposto dos cigarros teria um aumento de 32\% (IC: 27-37), representando um adicional de US\$ 7,05 bilhões (IC: 5,984-8,086) na receita. Quase todos os países demonstraram aumento na receita tributária, até mesmo nas extremidades da análise de sensibilidade.

Conclusão. Os resultados deste estudo confirmam que os benefícios esperados com o aumento dos impostos dos cigarros são consideráveis em toda a Região da ALC. Os países podem ter confiança de que aumentar as taxas tributárias dos cigarros gera receita tributária adicional.

Economia; impostos; saúde pública; América Latina; região do Caribe. 